\title{
Entrelacs
}

Cinéma et audiovisuel

HS | 2012

Le post-humain et les enjeux du sujet

\section{Méta-corps et immersion numérique}

\section{Éliane Chiron}

\section{OpenEdition}

\section{Journals}

Édition électronique

URL : http://journals.openedition.org/entrelacs/296

DOI : 10.4000/entrelacs.296

ISSN : 2261-5482

Éditeur

Éditions Téraèdre

Édition imprimée

Date de publication : 2 février 2012

ISBN : 978-2296567177

ISSN : 1266-7188

\section{Référence électronique}

Éliane Chiron, « Méta-corps et immersion numérique », Entrelacs [En ligne], HS | 2012, mis en ligne le

01 août 2012, consulté le 04 mai 2019. URL : http://journals.openedition.org/entrelacs/296 ; DOI :

10.4000/entrelacs.296

Ce document a été généré automatiquement le 4 mai 2019.

Tous droits réservés 


\section{Méta-corps et immersion numérique}

\section{Éliane Chiron}

1 Le texte complet de cet article est publié dans l'ouvrage :

Post humain et les enjeux du sujet

Editeur : L'HARMATTAN (2 février 2012)

Collection Ouverture Philosophique

ISBN-10 : 2296567177

ISBN-13 : 978-2296567177

\section{RÉSUMÉS}

Ce texte interroge essentiellement ce qui, dans l'usage créateur du numérique, serait artistique, au-delà de la technique inséparable du vivant.

\section{AUTEUR}

\section{ÉLIANE CHIRON}

Professeure des universités, Paris 1 Panthéon-Sorbonne, Directrice du CRAV (Centre de recherche en arts visuels) 